\title{
PKM Pembangkit Listrik Tenaga Hybrid di Desa Sabiyan Kabupaten Bangkalan
}

\author{
Riza Alfita*1, Rosida Vivin Nahari², Mirza Pramudia ${ }^{3}$, Kartika ${ }^{4}$ \\ 1,2,3Fakultas Teknik, Universitas Trunojoyo Madura \\ ${ }^{4}$ Fakultas Ekonomi, Universitas Jember \\ *e-mail: riza.alfita@trunojoyo.ac.id ${ }^{1}$, rosida.nahari@trunojoyo.ac.id ${ }^{2}$,pramudiamirza@trunojoyo.ac.id ${ }^{3}$ \\ ika_mlg0082@yahoo.co.id ${ }^{4}$
}

\begin{abstract}
The Community Partnership Program (PKM) is a community service program that carried out in the village assisted by the Electrical Engineering Study Program at the University of Trunojoyo Madura. the program is a continuation of the Real Work Lecture program (KKN) which is carried out in the Even semester 2019/2020 involving students, as well as village officials. The village of Sabiyan is located on the coast of Madura where the average population still relies on electricity for daily activities. The problems faced by the people of Sabiyan village Bangkalan Regency are: the people of Sabiyan Village do not yet have the knowledge and skills to utilize renewable energy, lighting facilities are still limited so that not all citizens can get electricity, the price of Basic Electricity Tariff (TDL) is higher so it is necessary renewable energy reserves. With these problems, it is necessary to have a hybrid power plant training. Based on the results of the pre-test conducted on the training participants, the average value was 62.50 and the post-test value was 75.83, with a paired sample correlation of -13.33 so that it could be concluded that there was an increase in knowledge after the training was held.
\end{abstract}

Keywords : PKM, Sabiyan Village, Hybrid

\begin{abstract}
Abstrak
Program Kemitraan Masyarakat (PKM) ini merupakan program pengabdian masyarakat yang dilaksanakan di desa binaan Prodi Teknik Elektro Universitas Trunojoyo Madura, program ini merupakan kelanjutan dari program Kuliah Kerja Nyata (KKN) yang dilaksanakan pada semester Genap 2019/2020 yang melibatkan mahasiswa, maupun perangkat desa. Desa Sabiyan terletak di pesisir Madura dan rata-rata penduduknya masih mengandalkan listrik untuk beraktifitas sehari-hari. Adapun permasalahan yang dihadapi oleh masyarakat desa Sabiyan Kabupaten Bangkalan yaitu : masyarakat Desa Sabiyan belum memiliki pengetahuan dan keterampilan untuk memanfaatkan energi terbarukan, fasilitas penerangan yang masih terbatas sehingga tidak semua warganya dapat aliran listrik, harga Tarif Dasar Listrik (TDL) yang semakin tinggi sehingga perlu adanya cadangan energi terbarukan. Dengan adanya permasalahan tersebut maka perlu adanya pelatihan pembangkit listrik Tenaga Hybrid. Berdasarkan hasil pre-test yang dilakukan terhadap peserta pelatihan didapatkan nilai rata-rata 62,50 dan nilai post-test 75,83, dengan paired sample correlation -13,33 sehingga dapat disimpulkan terdapat peningkatan pengetahuan setelah diadakan pelatihan.
\end{abstract}

Kata kunci: PKM, Desa Sabiyan, Hybrid

\section{PENDAHULUAN}

Kabupaten Bangkalan saat ini memiliki 273 desa, tetapi 24 desa masih terdaftar dalam desa tertinggal, hal ini disampaikan oleh Kepala Dinas Masyarakat dan desa (DPMD) Kabupaten Bangkalan, ketertinggalan ini disebabkan oleh Indeks Desa Membangun (IDM) yang masih terlalu rendah yaitu dibawah 0,592, selain itu tidak adanya pelayanan pendidikan, kesehatan dan aktifitas pusat perekonomian (https://www.kabarjawatimur.com/24-desa-di-bangkalanberstatus-desa-tertinggal/, n.d.). Pemerintah daerah berusaha menuntaskan desa tertinggal tersebut karena bantuan dari pemerintah akan disalurkan jika pada tahun 2021 desa tersebut tuntas dari daftar desa tertinggal. Desa Sabiyan merupakan desa yang terletak di Kecamatan Bangkalan yang mempunyai luas $1,6 \mathrm{~km}^{2}$, desa ini tidak terlalu luas karena Kecamatan Bangkalan hanya mempunyai luas $35,02 \mathrm{~km}^{2}$ dan penduduknya didominasi Perempuan (1443 Orang) dan laki-laki 141 orang (Bangkalan, 2018) 
Pemanfaatan energi terbarukan (EBT) di Indonesia masih relatif rendah, hal ini disebabkan oleh biaya investasi yang terlalu tinggi sehingga belum bisa bersaing dengan pembangkit fosil terutama batubara, selain hal tersebut kurangnya dukungan sektor industri dan pemerintah belum bisa memberikan pendanaan berbunga rendah sehingga perkembangan energi terbarukan masih jalan ditempat (ALFITA et al., 2020). Disektor transportasi pemerintah sudah mengatur campuran BBN ke Bahan Bakar Minyal sebesar 20\% (B20). Untuk mempercepat kebijakan energi terbarukan, pemerintah mulai membuat regulasi diantaranya adalah Peraturan Presiden No 4 Tahun 2016 (Pasal 14) mengenai akselerasi prasarana kelistrikan dengan pemanfaatan tenaga baru dan terbarukan. Pemerintah Pusat dan Pemerintah Daerah harus memberikan dukungan berupa pemberian insentif fiskal, kemudahan perizinan \& non-perizinan, penentuan harga beli tenaga listrik dari masing-masing jenis sumber tenaga baru \& terbarukan, pembentukan badan bisnis tersendiri pada rangka penyediaan energi listrik untuk dijual ke PT PLN (Persero), dan/atau penyiapan subsidi. Peraturan Presiden No. 66 Tahun 2018 mengenai Perubahan Kedua Atas Peraturan Presiden No. 61 Tahun 2015 tentang Penghimpunan \& Penggunaan Dana Perkebunan Kelapa Sawit, yg menetapkan Pendayagunaan biodiesel bagi PSO \& non PSO sesuai pasal 18 ayat (1b). Peraturan Menteri Keuangan No.177/PMK.011/2007 mengenai Pembebasan Bea Masuk atas Impor Barang untuk aktifitas Usaha Hulu Minyak dan Gas dan Panas Bumi. (Kementerian Energi dan Sumber Daya Mineral, 2017). Semakin menipisnya produksi minyak bumi di Indonesia serta kewajiban seluruh dunia dalam mengurangi emisi gas rumah kaca mendorong pemerintah Indonesia meningkatkan fungsi dari energi terbarukan yang dilakukan secara berkesinambungan untuk menjaga ketahanan energi nasional. Sesuai PP No 79 Tahun 2014 Tentang kebijakan energi secara nasional, target sebaran energi terbarukan yaitu mencapai $23 \%$ dan terus meningkat sampai dengan $31 \%$ pada tahun 2050, Indonesia mempunyai kemampuan yang sangat besar untuk mencapat target sebaran energi tersebut, seperti yang terlihat di tabel berikut :(Nasional, 2019)

Tabel 1. Kapasitas energi terbarukan Indonesia

\begin{tabular}{lc}
\hline \multicolumn{1}{c}{ Macam Energi } & Potensi \\
\hline Tenaga Matahari & $207,8 \mathrm{GW}$ \\
Tenaga Air & $94,3 \mathrm{GW}$ \\
Tenaga Angin & $60,6 \mathrm{GW}$ \\
PLT Bio & $32,6 \mathrm{GW}$ \\
Panas Bumi & $28,5 \mathrm{GW}$ \\
Energi Laut & $17,9 \mathrm{GW}$ \\
\hline
\end{tabular}

Sumber Ditjen EBTKE,(Nasional, 2019)

Berdasarkan Tabel 1. Terlihat bahwa tenaga matahari mempunyai potensi yang paling tinggi dibandingkan dengan energi lainnya, tetapi yang dimanfaatkan hanya sekitar 0,87 GW saja (Badan Litbang ESDM, 2012). Saat ini ekspansi Pembangkit listrik tenaga surya telah menjadi dasar yang kuat untuk kebijakan energi nasional, namun yang menjadi kendala adalah teknologi industri photovoltaic yang belum dapat memproduksi sendiri, dan masih import, saat ini Indonesia masih mampu memproduksi modul-modul solar panel dan mengintegrasikannya.(Kementerian Energi dan Sumber Daya Mineral, 2017)

Peraturan Presiden Nomor 2 Tahun 2015 elektrifikasi Indonesia mencapai 95,15\%. Melalui perpres tersebut PT PLN berusaha memenuhi standart tersebut sehingga pada akhir tahun 2018 tercatat elektrifikasi mencapai 98,30\% sehingga angka ini melebihi target rencana pembangunan jangka menengah nasional 2015-2019 (ESDM communication team, 2019) Rasio Elektrifikasi Indonesia sangat meningkat dalam 5 tahun terakhir, pada tahun 2014 elektrifikasi sebesar $84,35 \%$ dan menjadi $98,89 \%$ di tahun 2019. Berikut data daearah yang mempunyai elektrifikasi tergolong rendah 
Tabel 2. Elektrifikasi Indonesia (Humas EBTKE, 2019)

\begin{tabular}{lc}
\hline \multicolumn{1}{c}{ Provinsi } & Elektrifikasi \\
\hline Nusa Tenggara Timur (NTT) & $85 \%$ \\
Kalimantan Tengah & $94 \%$ \\
Sulawesi Utara & $94 \%$ \\
Maluku & $92 \%$ \\
Papua & $94 \%$ \\
\hline
\end{tabular}

Program pengabdian yang membahas tenaga surya telah banyak dilakukan diantaranya adalah pemanfaatan listrik tenaga surya bagi pedagang kuliner dikota Ambon, dimana rata-rata pedagang 99,7 \% menggunakan energi listrik dan sisanya menggunakan tenaga aki (Haryanto et al., 2019)(Parera, Tupalessy, \& Kastnaja, 2019), teknologi panel surya perahu nelayan, pengabdian ini membahas permasalahan lampu yang digunakan untuk mencari ikan (Mulyadi et al., 2018), penerapan perangkat otomatisasi dan monitoring tangki air di kampung MandianginSiak, pengabdian ini membahas otomatisasi tangki air menggunakan komponen-komponen dasar elektronika (Unik, 2019),

\section{METODE}

Berdasarkan prioritas permasalahan mitra, maka perlu dirumuskan beberapa solusi agar permasalahan tersebut dapat diselesaikan. Solusi yang ditawarkan melalui kegiatan ini dirumuskan dalam beberapa tahapan. Tahapan tersebut ditunjukkan berupa urutan langkah penyelesaian seperti gambar dibawah ini :

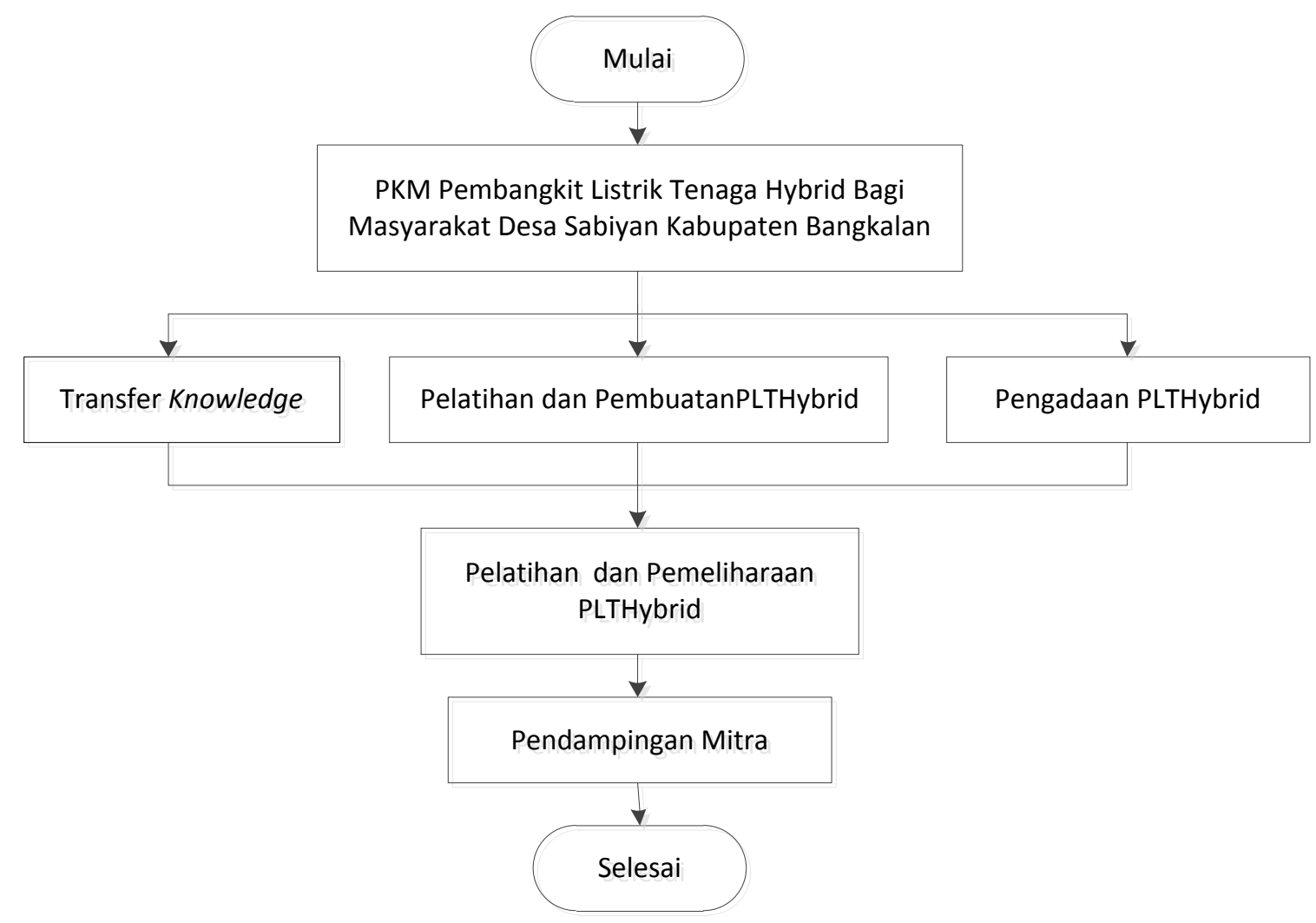

Gambar 1. Langkah pelaksanaan PKM Pembangkit Listrik Tenaga Hybrid

Program ini dilaksanakan dan diselesaikan dalam waktu 5 Bulan yang meliputi :

a. Persiapan pelaksanaan kegiatan pelatihan

- Merencanakan pelaksanaan kegiatan yang meliputi sosialisasi, pelatihan dan pendampingan 
- Pembuatan undangan sosialisasi untuk membahas pelaksanaan jadwal kegiatan pelatihan dan pendampingan

- Penyebaran undangan sosialisasi yang ditujukan ke masyarakat dengan tembusan ke Kepala Desa Sabiyan

- Kegiatan pendaftaran bagi peserta. Terdiri dari perangkat desa sebanyak 1 orang dan warga Desa Sabiyan sebanyak 5 orang, adanya warga masyarakat diharapkan dapat saling backup saat terjadi permasalahan pada saat Pembangkit Listrik Tenaga Hybrid diterapkan di Desa Sabiyan

- Peserta mempunyai pengetahuan yang cukup tentang peralatan elektronika

b. Persiapan Kelengkapan kegiatan, dalam tahapan ini beberapa kegiatan yang dilakukan diantaranya adalah

- Menjadwalkan peminjaman ruang di Desa Sabiyan Kabupaten Bangkalan

- Mempersiapakn seminar kit dan peralatan solar panel berbasis hybrid untuk peserta

- Mempersiapakn alat penunjang seperti solder, kabel,timah dan lain lain

- Pembuatan modul sebagai tutorial yang berisi materi-materi yang akan diberikan dalam pelatihan. Tutorial berupa teori dan latihan problem solving dengan tujuan memudahkan peserta dalam pemahaman materi

c. Pelaksanaan Pelatihan

Pelatihan dilaksanakan sesuai jadwal yang disepakati antara warga, perangkat desa dan masyarakat. Dalam pelatihan ini peserta akan didata ulang berdasarkan infomasi yang diperoleh pada saat daftar ulang. Materi pelatihan terdiri dari dasar-dasar elektronika (Resistor, kapasitor, transistor, inverter dan dasar pembangkit listrik tenaga surya)

d. Dokumentasi Akhir

Akhir dari kegiatan ini adalah pembuatan dokumentasi kegiatan dan laporan akhir

\section{HASIL DAN PEMBAHASAN}

Program Pengabdian Kepada Masyarakat ini dilakukan dalam 2 tahap, tahap pertama akan dilakukan recruitment peserta pelatihan yang berkerjasama dengan kepala desa untuk menjaring warga masyarakat yang mempunyai minat dan bakat dibidang elektronika, para peserta akan diberikan soal pretest dalam bentuk pertanyaan, pretest ini diberikan dengan maksud untuk mengukur seberapa besar tingkat pengetahuan peserta mengenai materi yang akan diberikan, meliputi elektronika dasar dan pembangkit listrik tenaga surya, adapun manfaat yang dapat diperoleh dari kegiatan pretest ini yaitu tim pengabdi dapat mengetahui sejauh mana kemampuan peserta pelatihan sehingga tim dapat menentukan cara penyampaian materi. Tahap berikutnya yaitu mereka akan diberikan pelatihan mengenai cara-cara menggunakan multimeter digital maupun analog, berikutnya akan diberikan pelatihan mengenai dasar-dasar elektronika yang meliputi, resistor, kapasitor, transitor, dihari kedua peserta akan diberikan materi mengenai panel surya, baik itu prinsip kerja, cara merangkai maupun trouble shooting.

Kegiatan pengabdian kepada masyarakat ini diakhiri dengan post-test yang diberikan dalam bentuk pertanyaan sebagai evaluasi akhir terhadap materi yang telah diujikan. Manfaat dari post-test ini yaitu untuk memperoleh gambaran tentang kemampuan masyarakat yang telah diberikan pelatihan Hasil dari pretest dan posttest ini akan digunakan sebagai parameter apakah kegiatan yang dilakukan berpengaruh terhadap kemampuan peserta pelatihan. 


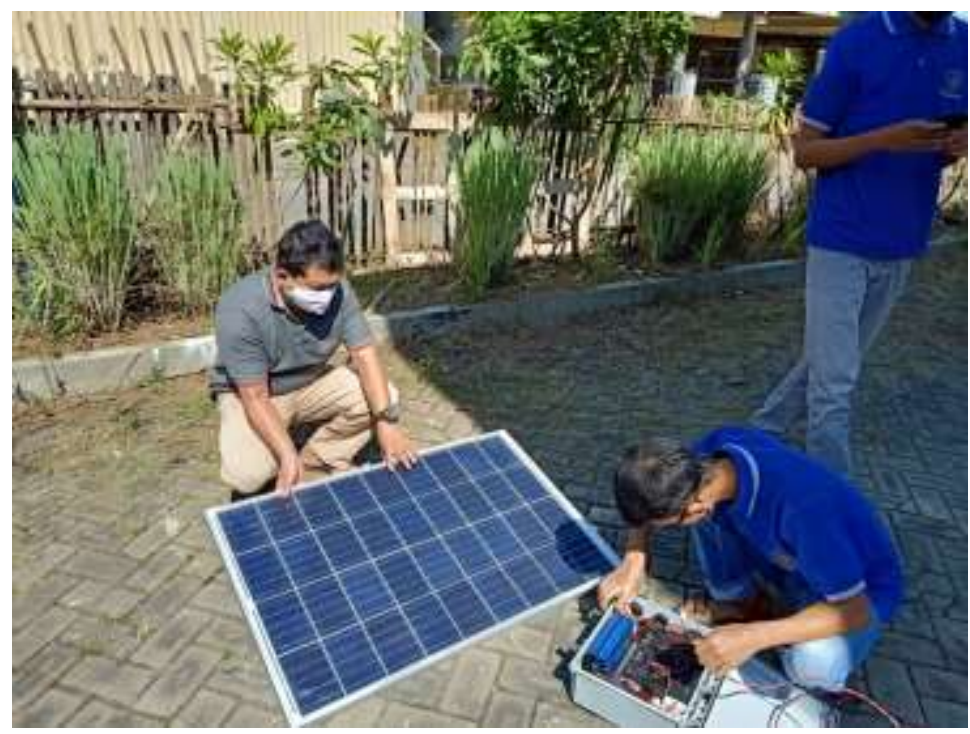

Gambar 1. Pelatihan trouble shooting PLTS

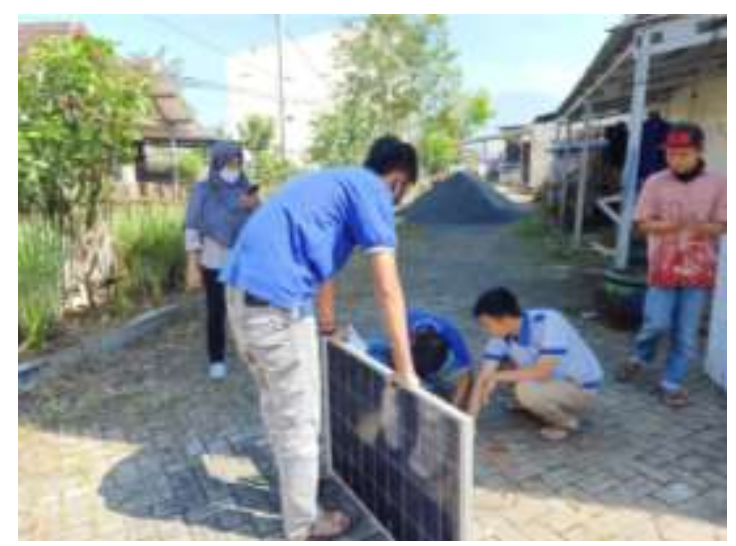

Gambar 2. Pelatihan perakitan PLTS

Berikut disajikan nilai pre test dan post test peserta pelatihan

Tabel 3. Hasil Pretest dan Posttest

\begin{tabular}{cccc}
\hline No & Peserta & Nilai Pre Test & Nilai Post Test \\
\hline 1 & Peserta 1 & 50 & 60 \\
2 & Peserta 2 & 60 & 70 \\
3 & Peserta 3 & 70 & 80 \\
4 & Peserta 4 & 75 & 90 \\
5 & Peserta 5 & 60 & 80 \\
6 & Peserta 6 & 60 & 75 \\
\hline
\end{tabular}

Berdasarkan nilai pretest dan posttest tersebut maka dapat dianalisa dengan menggunakan software PSPP yang merupakan software GNU (General Public License).

Tabel 4. Paired sample statistics

\begin{tabular}{|c|c|c|c|c|c|}
\hline & & Mean & $\mathrm{N}$ & Std. Deviation & S.E. Mean \\
\hline \multirow[t]{2}{*}{ Pair } & Pre_Test & 62,50 & 6 & 8,80 & 3,59 \\
\hline & Post_Test & 75,83 & 6 & 10,21 & 4,17 \\
\hline
\end{tabular}


Berdasakan Tabel 4. Paired Sample Statistics didapatkan nilai rata-rata untuk pre-test yaitu 62,50 dan rata-rata nilai post-test adalah 75,83 dengan jumlah peserta (N) 6 orang. Dengan standart deviasi pre-test 8,80 dan post-test sebesar 10,21.

Tabel 5. Paired samples correlation

\begin{tabular}{ccccc}
\hline & Mean & N & Sig \\
\hline Pair & Pre Test \& Post Test & 6 & 0,92 & 0,0 \\
\hline
\end{tabular}

Berdasarkan tabel 5. paired samples correlation terdapat Sig. (2-tailed) bernilai 0 yang berarti ada perbedaan signifikan antara penilaian pre-test dan penilaian post-test karena nilai $\mathrm{p}$ value $0<0,05$ (95\% kepercayaan). Output nilai korelasi antara 2 variabel (variabel pre-test dan post-test) didapatkan 0,92 artinya terdapat hubungan yang kuat dan positif antara hasil pre-test dan post-test.

Tabel 6. Paired sample correlation

\begin{tabular}{|c|c|c|c|c|c|c|c|c|}
\hline & \multicolumn{5}{|c|}{ Paired Differences } & \multirow{3}{*}{$\mathrm{t}$} & \multirow{3}{*}{$\mathrm{df}$} & \multirow{3}{*}{$\begin{array}{l}\text { Sig. (2 } \\
\text { Tailed) }\end{array}$} \\
\hline & \multirow[t]{2}{*}{ Mean } & \multirow[t]{2}{*}{$\begin{array}{l}\text { Std. } \\
\text { Deviat } \\
\text { ion }\end{array}$} & \multirow[t]{2}{*}{$\begin{array}{l}\text { Std. } \\
\text { Error } \\
\text { Mean }\end{array}$} & \multicolumn{2}{|c|}{$\begin{array}{l}95 \% \text { Confidence } \\
\text { Interval of The } \\
\text { Diference }\end{array}$} & & & \\
\hline & & & & Lower & Upper & & & \\
\hline $\begin{array}{c}\text { Pre_Test - } \\
\text { Post Test }\end{array}$ & $-13,33$ & 4,08 & 1,67 & $-17,62$ & $-9,05$ & $-8,00$ & 0,00 & 0 \\
\hline
\end{tabular}

Berdasarkan tabel paired sample correlation didapatkan mean: -13,33 (bernilai negatif) yang berarti terjadi kecenderungan peningkatan pengetahuan setelah adanya pelatihan solar sell, Rata-rata peningkatannya adalah 13,33.

\section{KESIMPULAN}

Berdasarkan hasil pelatihan pembangkit listrik tenaga hybrid yang dilaksanakan di desa Sabiyan Kabupaten bangkalan maka dapat disimpulkan sebagai berikut

a. Nilai rata-rata pretest yaitu 62,50 dan post test yaitu 75,83 yang berarti terdapat peningkatan pengetahuan setelah diadakan pelatihan pembangkit listrik tenaga surya di desa Sabiyan Kabupaten Bangkalan

b. Masyarakat mulai bisa memanfaatkan energi alternatif untuk mendukung kebijakan pemerintah tentang energi Nasional

\section{UCAPAN TERIMA KASIH}

Penulis mengucapkan terima kasih kepada Lembaga Penelitian dan Pengabdian Kepada Masyarakat Universitas Trunojoyo Madura dan Deputi Bidang Penguatan Riset dan Pengembangan, Kementerian Riset dan Teknologi / Badan Riset dan inovasi Nasional yang telah memberi dukungan finansial terhadap pengabdian ini.

\section{DAFTAR PUSTAKA}

Alfita, R., Ibadillah, A. F., Rahmawati, D., Kusuma, M. K. H., Kurniawan A., Nahari, R. V., \& Pramudia, M. (2020). Perancangan Solar Tracker Four Axis Berbasis Internet of Things (IoT). ELKOMIKA: Jurnal Teknik Energi Elektrik, Teknik Telekomunikasi, \& Teknik Elektronika, 8(2), 404. https://doi.org/10.26760/elkomika.v8i2.404

Badan Litbang ESDM. (2012). Matahari Untuk PLTS di Indonesia. Kementrian ESDM, 1. Retrieved from 
http://www.litbang.esdm.go.id/index.php?option=com_content\&view=article\&id=541:mata hari-untuk-plts-di-indonesia\&catid=129:plts-plts\&Itemid $=172$

Bangkalan, B. P. S. K. (2018). Kabupaten Bangkalan Dalam Angka 2018. Retrieved from https://bangkalankab.bps.go.id/publication/download.html?nrbvfeve=ZGExMGRhMGVmZD JjNTg4NTA0YjE3ODg5\&xzmn=aHR0cHM6Ly9iYW5na2FsYW5rYWIuYnBzLmdvLmlkL3B1Y mxpY2F0aW9uLzIwMTgvMDgvMTYvZGExMGRhMGVmZDJjNTg4NTA0YjE30Dg5L2thYnVw YXRIbi1iYW5na2FsYW4tZGFsYW0tYW5na2EtMjA

ESDM communication team. (2019). Tidak Lagi Defisit, Sistem Kelistrikan Indonesia Semakin Andal. Kementerian Energi Dan Sumber Daya Mineral Republik Indonesia Siaran Pers Nomor: 322.Pers/04/SJI/2019.

Haryanto, Ulum, M., Ibadillah, A. F., Alfita, R., Aji, K., \& Rizkyandi, R. (2019). Smart aquaponic system based Internet of Things (IoT). Journal of Physics: Conference Series, 1211(1). https://doi.org/10.1088/1742-6596/1211/1/012047

https://www.kabarjawatimur.com/24-desa-di-bangkalan-berstatus-desa-tertinggal/. (n.d.). No Title.

Humas EBTKE. (2019). Rasio Elektrifikasi 99,9\% Tahun 2019.

Kementerian Energi dan Sumber Daya Mineral. (2017). Kajian Penyediaan dan Pemanfaatan Migas, Batubara, Ebt dan Listrik. In Pusat Data dan Teknologi Informasi Energi dan Sumber Daya Mineral Kementerian Energi dan Sumber Daya Mineral. Retrieved from https://www.google.com/url?sa=t\&rct=j\&q=\&esrc=s\&source=web\&cd=1\&cad=rja\&uact=8\& ved=2ahUKEwjHsaPE2vPlAhX7wzgGHdZWBvYQFjAAegQIBBAC\&url=https\%3A\%2F\%2Fww w.esdm.go.id $\% 2$ Fassets $\% 2$ Fmedia $\% 2$ Fcontent $\% 2$ Fcontent-kajian-penyediaan-danpemanfaatan-energi-2017.pdf\&usg=AO

Mulyadi, M., Musa, L. O., Yunus, M. Y., Jurusan, D., Mesin, T., Negeri, P., \& Pandang, U. (2018). Teknologi panel surya perahu nelayan. Seminar Nasional Hasil Penelitian Dan Pengabdian Kepada Masyarakat (SNP2M), 2018, 66-69.

Nasional, D. E. (2019). Indonesia Energy Outlook 2019. In Journal of Chemical Information and Modeling (Vol. 53). https://doi.org/10.1017/CB09781107415324.004

Parera, L. M., Tupalessy, J., \& Kastnaja, R. (2019). Pengembangan Listrik Tenaga Surya bagi Pedagang Kuliner. CARADDE: Jurnal Pengabdian Kepada Masyarakat, 2(1). https://doi.org/10.31960/caradde.v2i1.127

Unik, M. (2019). Penerapan Perangkat Otomatisasi Dan Monitoring Tangki Air di Kampung Mandangin-Siak. Dinamisia: Jurnal Pengabdian Kepada Masyarakat, 3. https://doi.org/10.31849/dinamisia.v3i2.2839 